Creative Commons User License: CC BY-NC-ND

Abstracted by: EBSCOhost, Electronic Journals Service (EJS),

Google Scholar, Journal Seek, Scientific Commons,

Food and Agricultural Organization (FAO), CABI and Scopus

http://eoi.citefactor.org/10.11226/v25i2
Journal of Agricultural Extension

Vol. 25 (2) April, 2021

ISSN(e): 24086851; ISSN(Print); 1119944X

http://journal.aesonnigeria.org

http://www.ajol.info/index.php/jae

Email: editorinchief@aesonnigeria.org

\title{
Use of Improved Production Technologies Among Goat Farmers in Abia State Nigeria \\ https://dx.doi.org/10.4314/jae.v25i2.9
}

\section{Obinna Leo 0}

Department of Agricultural Extension and Rural Develeopment

Michael Okpara University of Agriculture, Umudike

Email: Obinna.leo2@gmail.com; Phone: +2348035454465

\section{Onu Samson Ejike}

Department of Agricultural Extension and Rural Develeopment

Michael Okpara University of Agriculture, Umudike

Email: samsononu@gmail.com, Phone: +2348134870488

\section{Abstract}

The study provided an empirical evidence on the use of improved goat production technologies among rural farmers in Abia State, Nigeria. The specific objectives of the study were, ascertain the extent of use of improved goat production technologies, determine factors influencing use of improved goat production technologies and identify constraints to access and use of improved goat production technologies. A multi-stage random sampling procedure was adopted in selecting 120 respondents. Data were collected through the use of questionnaire and analysed with frequency, percentage, mean and regression model. Respondents were aware of dipping (100\%), deworming (99.2\%) fostering of kids (93.3\%) and colostrum feeding (71.7\%), among others. On extent of use of improved goat production technologies, respondents highly used most of improved goat production technologies [grand mean $=\bar{x}=3.20$ ]. All the respondents [100\%] agreed that lack of access to credit was a constraint to use, $100 \%$ agreed on lack of credibility from source of technological information, 99.2\% agreed that they were afraid of taking risk, 93.3\% agreed on difficulty in technology application, among others. Age education, household size, farming experience, farm size, income and access to credit were the determinants of use of improved goat production technologies at 5\% level of probability Greater use of available improved technologies will promote productivity, and therefore there is need for proper sensitization and awareness by relevant agencies. Again, credit should be made available to farmers by relevant governmental and nongovernmental agencies to increase the level of use of available improved technologies.

Keywords: improved goat production technologies and farmers

\section{Introduction}

Goats are among the main meat-producing animals in Nigeria, whose meat is one of the choicest and has high demand across the country. Besides meat, goats provide other products like milk, skin, fiber and manure. Nigeria, with over 3.9 million goats is one of the largest goat producing countries in Africa and playing a significant role in livelihood and nutritional security as well as providing supplementary income to 
Creative Commons User License: CC BY-NC-ND

Abstracted by: EBSCOhost, Electronic Journals Service (EJS),

Google Scholar, Journal Seek, Scientific Commons,

Food and Agricultural Organization (FAO), CABI and Scopus

http://eoi.citefactor.org/10.11226/v25i2
Journal of Agricultural Extension

Vol. 25 (2) April, 2021

ISSN(e): 24086851; ISSN(Print); 1119944X

http://journal.aesonnigeria.org

http://www.ajol.info/index.php/jae

Email: editorinchief@aesonnigeria.org

many marginal and resource poor farmers, (Food and Agricultural Organization; $\mathrm{FAO},:$ 2015)

Goat production constitutes a very important part of the rural economy with more than $95 \%$ of the rural households keeping goats and ranks next to cattle in income generation and economic sustenance (Nwachukwu and Berekwu, 2020). Goats are owned by rural farmers within all age range and genders. Southeast Nigeria at extensive and semi-extensive systems as fodder is supplemented to goat production with household kitchen waste. Indigenous goats are primarily reared under traditional free-range system, characterized by high mortality, high morbidity and low productivity. In tropical environments, small ruminant(goat) production systems are characterised by low performance compared to temperate breeds as animals are either allowed to roam or graze for hours daily or permanently confined (Bishop and Morris 2017).

However, the productivity of goats under the traditional production system is very low owing to their maintenance under extensive system on natural vegetation and shrinking common grazing lands and tree lopping and the use of obsolete production technology. The adoption is low in important scientific practices due to lack of exposure, henceforth extension agencies have to arrange training and demonstration programmes of improved practices for goat keepers (Singh, 2017).

Technology information usage on the other hand refers to the physical and mental acts involved in incorporating improved technologies found, into farmers existing technology base. Farmers technology use is an indicator of technology needs, because it helps farmers to meet their needs. Technology use is concerned with what happens with a technology once it has been obtained, and how it is applied to accomplish a specific task.

Goat rearing using improved management practices undertaken for maximization of returns from the enterprise is considered as 'commercial goat farming' in the present context. The trend of commercialization has especially been prominent in the Northern states of Nigeria, where demand for marketing is relatively better. Goat production can be singled out to be an ideal option for the South Eastern part of Nigeria, given the abundance of suitable rangelands and the accommodating climatic conditions in the area.

In order to make the goat rearing a profitable enterprise, technologies have been developed by the research institutions both at national and international level (Susan, McCoard $^{a}$, Travis and Whitney ${ }^{c}, 2020$ ). Such improved practices developed have not been adopted by the farmers so far. Therefore, proper adoption of these improved practices by the goat farmers will be the only means to hasten further development in this sector. Improved technologies are various technical know-how for the promotion and development of agriculture. However in developing countries some of these technologies have been rejected by rural farmers, giving rise to the need to examine technologies used by rural farmers in a particular locality so as to 
Creative Commons User License: CC BY-NC-ND

Abstracted by: EBSCOhost, Electronic Journals Service (EJS),

Google Scholar, Journal Seek, Scientific Commons,

Food and Agricultural Organization (FAO), CABI and Scopus

http://eoi.citefactor.org/10.11226/v25i2
Journal of Agricultural Extension

Vol. 25 (2) April, 2021

ISSN(e): 24086851; ISSN(Print); 1119944X

http://journal.aesonnigeria.org

http://www.ajol.info/index.php/jae

Email: editorinchief@aesonnigeria.org

identify and meet their needs (Koirala,. Dutta, Dhakal., \& Pant, 2018). Keeping in view the above facts, the present research was designed to study the utilization level of improved goat farming technologies by goat farmers.

Technological and management options are the only alternatives to accelerate growth in the productivity of goats, which is low in the traditional system of production. The use of improved production technologies for commercial goat production system need to be used as recommended for effective and improved productivity. Improved production technology which were disseminated by Abia State Agricultural Development Programme as listed below is more economical than traditional system of production.

Table 1: Improved goat production technologies Categories List of improved goat production technologies

Housing

Recommended floor space for goats, Orientation (E-W) of goat shed, Use of feeding and, watering devices, Adoption of slatted floor housing, Goats raised on platforms (Sleeping quarters), Proper drainage facility

Feeding:

Feeding of concentrates at recommended quantity, feeding mineral supplements, Flushing prior to breeding, Colostrum feeding to kids ( $<1 \mathrm{hr}$. after birth), formulation of concentrates, Fodder cultivation practices.

Breeding: Identification of Does in heat, Pregnancy verification, Artificial Insemination (Al), Appropriate age of breeding in Does, changing buck at recommended intervals.

Disease control: Deworming, Dipping, Vaccination, Farm disinfection, Isolation of sick animals.

General management: Weaning, Tagging, Odour transfer, Farm fumigation, Fostering, Hoof trimming, Farm record maintenance, Castration of kids

Source: Abia State Agricultural Development Programme (ASADP), 2019

Statistics show that the supply of goat meat fell short of it's demand. Peacock (2015), asserts that while the average growth rate of the Nigerian population is between 2.5 $3.0 \%$ per annum, domestic food production lags behind at a growth rate less than $2 \%$ per annum, thereby creating food supply gap.

Despite the multiple roles goats play in the livelihood of rural farmers and the economic growth of the country, they are still neglected by farmers and sources of credit. For efficient production in the goat production enterprise, a lot of improved technologies have been developed and transferred to the field for use. There is little or no information on how farmers adopt and use these technologies, hence this study was conducted to investigate the use of improved goat production technologies among farmers in Abia state. 
Creative Commons User License: CC BY-NC-ND

Abstracted by: EBSCOhost, Electronic Journals Service (EJS),

Google Scholar, Journal Seek, Scientific Commons,

Food and Agricultural Organization (FAO), CABI and Scopus
Journal of Agricultural Extension

Vol. 25 (2) April, 2021

ISSN(e): 24086851; ISSN(Print); 1119944X

http://journal.aesonnigeria.org

http://www.ajol.info/index.php/jae

Email: editorinchief@aesonnigeria.org

\section{Specific objectives of the study}

- examine respondent's awareness of improved goat production technologies

- ascertain the extent of use of improved goat production technologies

- determine factors influencing use of improved goat production technologies

- ascertain constraints to use of existing improved technologies.

\section{Hypothesis}

Ho1: There is no significant difference between farmers socioeconomic characteristics and the extent of use of improved goat production technologies.

\section{Methodology}

The study was conducted in Abia State. Abia State lies within longitude $7^{0} 23 \mathrm{E}$ and $8^{0} 2 \mathrm{E}$ and latitude $4^{0} 47 \mathrm{~N}$ and $6^{0} 12 \mathrm{~N}$. According to National Population Commission, 2007 census report, Abia State has a population of 2,833,999 people, made up of $1,454,195$ males and $1,599,806$ females, and the population is predominately rural $(62.25 \%)$ with only $37.75 \%$ urban population. The population of the study comprised of all the goat farmers in Abia State, Nigeria. A multi-stage random sampling technique was adopted in selecting the sample of 120 respondents. In the first stage, two agricultural blocks each were randomly selected from the three Agricultural Zones in Abia State making a total six agricultural blocks. In the second stage, two circles each were randomly selected from the six agricultural blocks making a total of 12 circles. In the third stage, 2 cells each were randomly selected from the circles making a total 24 cells. In the fourth stage five (5) goat farmers were randomly selected from each of the cells which gave a total of 120 respondents.. Data for the study were collected through the use of questionnaire. Data were collected on all the specific objectives of the study and were analysed with both descriptive and inferential statistics. Objective one and four were analyzed using frequency and percentage, objective two was analyzed using mean count and standard deviation while objective three was analyzed with ordinary least square regression model.

Ho1: There is no significant relationship between farmer's socio-economic characteristics and the level of use of improved goat production technologies in the study area was tested using Ordinary Least Square regression model.

The OLS/multiple regression was expressed implicitly as follows.

$\mathrm{Y}=f\left(\mathrm{X}_{1} \mathrm{X}_{2} \mathrm{X}_{3} \mathrm{X}_{4} \mathrm{X}_{5} \mathrm{X}_{6} \mathrm{X}_{7}, \mathrm{X}_{8} \mathrm{X}_{9} \mathrm{X}_{10} \mathrm{X}_{11} \mathrm{X}_{12}, \mathrm{X}_{13}\right.$, ei $)$

The four functional forms of OLS in explicit form is specified as;

Linear Function

$Y=B+B_{1}+X_{1}+B_{2} X_{2}+$ $\beta_{n} X_{n+}$ ei

Exponential function

$\log Y=B+B_{1}+X_{1}+B_{2} X_{2}+$ $\beta_{n} X_{n}+e i$

Semi-log function

$Y=B_{0}+\beta_{1} \ln x_{1}+B_{2} \ln x_{2}$ Bnlnxn+ei

Cobb Douglas function 
Creative Commons User License: CC BY-NC-ND

Abstracted by: EBSCOhost, Electronic Journals Service (EJS), Google Scholar, Journal Seek, Scientific Commons,

Food and Agricultural Organization (FAO), CABI and Scopus

http://eoi.citefactor.org/10.11226/v25i2
Journal of Agricultural Extension

Vol. 25 (2) April, 2021

ISSN(e): 24086851; ISSN(Print); 1119944X

http://journal.aesonnigeria.org

http://www.ajol.info/index.php/jae

Email: editorinchief@aesonnigeria.org

$\log Y=\beta_{0}+\beta_{1} \ln x_{1}+\beta_{2} \ln X_{2}$ $ß_{n} \ln x_{n}+$ ei

Where,

$\mathrm{Y}=$ use of improved got production technologies (mean score)

$\mathrm{X}_{1}=$ age (years)

$\mathrm{X}_{2}=$ education level (Number of years spent in school)

$\mathrm{X}_{3}=$ marital status $(1=$ married, $0=$ single $)$

$X_{4}=$ flock size (number of goats)

$\mathrm{X}_{5}=$ farmers experience (years)

$\mathrm{X}_{6}=$ household size (number of persons)

$X_{7}=$ occupation ( farming $=1$, trading $=2$, civil service $=3$, artisan $=4$ )

$\mathrm{X}_{8}=$ farm income $(\mathrm{A})$

$\mathrm{X}_{9}=$ access to credit (yes $=1 \mathrm{No}=2$ )

$\mathrm{X}_{10}=$ membership of cooperative (yes $=1$, No $=0$ )

$\mathrm{e}=$ error term

\section{Results and Discussion}

\section{Awareness of Improved Goat Production Technologies}

Table 2 shows the distribution of respondents based on their awareness of improved goats production technologies in the study area. The result revealed that the respondents were aware of dipping (100\%), deworming (99.2\%),fostering of kids $(93.3 \%)$,colostrum feeding $(71.7 \%)$, slated floor system (70.8\%), giving mineral supplement $(70 \%)$ flushing does $(65.8 \%)$, farm fumigation and disinfection $(64.2 \%)$, odour transfer $(57.5 \%)$, goats raised on platforms $(55 \%)$, cross breeding $(54.2 \%)$, vaccination $(52.5 \%)$, feeding goats with concentrates $(52.5 \%)$, identification of does on heat $(50.8 \%)$. 
Creative Commons User License: CC BY-NC-ND

Abstracted by: EBSCOhost, Electronic Journals Service (EJS), Google Scholar, Journal Seek, Scientific Commons,

Food and Agricultural Organization (FAO), CABI and Scopus

http://eoi.citefactor.org/10.11226/v25i2
Journal of Agricultural Extension

Vol. 25 (2) April, 2021

ISSN(e): 24086851; ISSN(Print); 1119944X

http://journal.aesonnigeria.org

http://www.ajol.info/index.php/jae

Email: editorinchief@aesonnigeria.org

Table 2: Awareness of improved goat production technologies

\begin{tabular}{lc}
\hline Improved technologies in goat production & Percentages $^{\star}$ \\
\hline Slated floor system & 70.8 \\
Goat raised on platforms & 55.0 \\
Formulation of concentrates & 28.3 \\
Feeding goats with concentrates & 52.5 \\
Giving mineral supplement & 70.0 \\
Identification of does on heat & 50.8 \\
Cross breeding & 54.2 \\
Vaccination & 52.5 \\
Flushing of does & 65.8 \\
Colostrum feeding & 71.7 \\
Farm fumigation or disinfection & 64.2 \\
Deworming & 99.2 \\
Dipping & 100.0 \\
Fostering of kids & \\
Odour transfer & 93.3 \\
\hline Source: Field data, & 57.5
\end{tabular}

Source: Field data, 2019. *Multiple responses

The result implied that many farmers were very much aware of the various available improved production technologies. Awareness of an available technology is a prerequisite for accessing and using it. This is in agreement with the findings of Krishna, Mahesh, Lal, Santosh, and Bishnu, (2019), that farmers have very high awareness of associated technologies

\section{Extent of Use of Improved Goat Production Technologies}

Table 3 reveals a grand mean of 3.20 implying a high level of use of the improved goat production technologies. The result revealed that the respondents used the slated floor system ( $\bar{x}=3.65$ ), vaccination ( $\bar{x}=3.34$ ), goats raised on plateforms ( $\bar{x}_{=}$

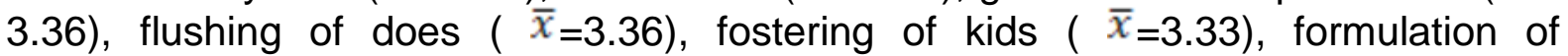
concentrates $(\bar{x}=3.29)$, colostrum feeding $(\bar{x}=3.29)$, feeding goats with concentrate ( $\bar{x}=3.28$ ), farm fumigation and disinfection $(\bar{x}=3.28)$, changing of bucks ( $\bar{x}=3.27$ ), crosss breeding ( $\bar{x}=3.08)$, odour transfer $(\bar{x}=3.00)$, dipping $(\bar{x}=2.93)$, Deworming $(\bar{x}=2,92)$, giving mineral supplement ( $\bar{x}=2.92)$. 
Creative Commons User License: CC BY-NC-ND

Abstracted by: EBSCOhost, Electronic Journals Service (EJS),

Google Scholar, Journal Seek, Scientific Commons,

Food and Agricultural Organization (FAO), CABI and Scopus

http://eoi.citefactor.org/10.11226/v25i2
Journal of Agricultural Extension

Vol. 25 (2) April, 2021

ISSN(e): 24086851; ISSN(Print); 1119944X

http://journal.aesonnigeria.org

http://www.ajol.info/index.php/jae

Email: editorinchief@aesonnigeria.org

Table 3: Extent of use of improved goat production technologies

\begin{tabular}{llc}
\hline $\begin{array}{l}\text { Extent of use of improved goat production } \\
\text { technologies }\end{array}$ & $\bar{x}$ & Std. Dv. \\
\hline Slated floor system & 3.65 & 0.60 \\
Goat raised on platforms & 3.36 & 0.56 \\
Formulation of concentrates & 3.29 & 0.58 \\
Feeding goats with concentrates & 3.28 & 0.52 \\
Giving mineral supplement & 2.92 & 0.60 \\
Identification of does on heat & 2.93 & 0.93 \\
Cross breeding & 3.08 & 0.62 \\
Vaccination & 3.43 & 0.63 \\
Flushing of does & 3.36 & 0.51 \\
Colostrum feeding & 3.29 & 0.52 \\
Farm fumigation or disinfection & 3.28 & 0.57 \\
Deworming & 2.92 & 0.57 \\
Dipping & 2.93 & 0.76 \\
Are you aware that bucks (male goats) are to be \\
changed at recommended intervals & 3.27 & 0.71 \\
Fostering of kids & & \\
Odour transfer & 3.33 & 0.66 \\
Grand mean & 3.00 & 0.60 \\
\hline Source: Fild Survey, & 3.20 & \\
\hline
\end{tabular}

Source: Field Survey, 2019

The result implied that respondents in the study area made use of the improved goats production technologies leading to higher productivity and generation of income. Karbo, Otchere, Bruce, Salia, and Honya (2017) in agreement with the study found that farmers in Ghana highly utilized improved goat production technologies.

\section{Factors Influencing Use of Improved Goat Production Technologies}

Table 4 shows the ordinary least square regression estimates of the socio-economic determinants of extent of use of improved goat production technologies in the study area. Four functional forms of multiple regressions were analyzed and Double-log functional form was selected based on magnitude of the $R^{2}$ value, number of significant variables and $\mathrm{F}$ - ratio. The $\mathrm{R}^{2}$ (coefficient of multiple determination) value was 0.765 which implied that $76.5 \%$ of the total observed variations in the dependent variable $(\mathrm{Y})$ were accounted for while $23.5 \%$ of the variation was due to error. Fstatistics was significant at $1 \%$ indicating the fitness of the model used. 
Creative Commons User License: CC BY-NC-ND

Abstracted by: EBSCOhost, Electronic Journals Service (EJS), Google Scholar, Journal Seek, Scientific Commons,

Food and Agricultural Organization (FAO), CABI and Scopus

http://eoi.citefactor.org/10.11226/v25i2
Journal of Agricultural Extension

Vol. 25 (2) April, 2021

ISSN(e): 24086851; ISSN(Print); 1119944X

http://journal.aesonnigeria.org

http://www.ajol.info/index.php/jae

Email: editorinchief@aesonnigeria.org

Table 4: Multiple regression estimate of the determinants of use of improved goat production technologies

\begin{tabular}{|c|c|c|c|c|}
\hline Variables & Linear & Exponential & Semi-Log & + Double Log \\
\hline (Constant) & $\begin{array}{l}-2338.142 \\
(-0.032)\end{array}$ & $\begin{array}{l}8.980 \\
(9.566)^{\star * *}\end{array}$ & $\begin{array}{l}103387.027 \\
(4.714)^{\star * *}\end{array}$ & $\begin{array}{l}11.173 \\
(4.507)^{\star \star *}\end{array}$ \\
\hline Age & $\begin{array}{l}-194.886 \\
(-0.255)\end{array}$ & $\begin{array}{l}0.007 \\
(0.681)\end{array}$ & $\begin{array}{l}-37351.323 \\
(-0.972)\end{array}$ & $\begin{array}{l}-.773 \\
(-1.779)^{*}\end{array}$ \\
\hline Marital status & $\begin{array}{l}-26405.1 \\
(-3.097)^{\star * *}\end{array}$ & $\begin{array}{l}-0.303 \\
(-2.794)^{* *}\end{array}$ & $\begin{array}{l}-28338.511 \\
(1.236)\end{array}$ & $\begin{array}{l}-0.417 \\
(1.361)\end{array}$ \\
\hline Years of Education & $\begin{array}{l}3244.229 \\
(1.805)^{\star}\end{array}$ & $\begin{array}{l}0.064 \\
(2.501)^{\star *}\end{array}$ & $\begin{array}{l}-34888.386 \\
(1.151)\end{array}$ & $\begin{array}{l}1.149 \\
(3.355)^{\star \star \star}\end{array}$ \\
\hline Household size & $\begin{array}{l}-302.356 \\
(-0.122)\end{array}$ & $\begin{array}{l}0.005 \\
(0.172)\end{array}$ & $\begin{array}{l}1376.132 \\
(0.106)\end{array}$ & $\begin{array}{l}.068 \\
(3.461)^{\star * *}\end{array}$ \\
\hline Farming experience & $\begin{array}{l}1950.902 \\
(1.983)^{\star *}\end{array}$ & $\begin{array}{l}0.010 \\
(0.832)\end{array}$ & $\begin{array}{l}14972.501 \\
(4.160)^{* * *}\end{array}$ & $\begin{array}{l}.089 \\
(3.767)^{\star * *}\end{array}$ \\
\hline Farm size & $\begin{array}{l}0.054 \\
(0.247)\end{array}$ & $\begin{array}{l}1.766 \mathrm{E}-6 \\
(0.633)\end{array}$ & $\begin{array}{l}8394.982 \\
(0.767)\end{array}$ & $\begin{array}{l}.048 \\
(3.390)^{\star * *}\end{array}$ \\
\hline Monthly income & $\begin{array}{l}0.422 \\
(2.071)\end{array}$ & $\begin{array}{l}1.823 E-6 \\
(0.705)\end{array}$ & $\begin{array}{l}474.305 \\
(2.037)^{* *}\end{array}$ & $\begin{array}{l}.113 \\
(5.768)^{\star \star *}\end{array}$ \\
\hline Access to Credit & $\begin{array}{l}-0.057 \\
(-0.637)\end{array}$ & $\begin{array}{l}\text { 1.967E-6 } \\
(1.740)^{*}\end{array}$ & $\begin{array}{l}4482.591 \\
(4.112)^{* * *}\end{array}$ & $\begin{array}{l}.288 \\
(2.60)^{\star *}\end{array}$ \\
\hline Cooperative membership & $\begin{array}{l}39594.605 \\
(0.651)\end{array}$ & $\begin{array}{l}0.659 \\
(0.473)\end{array}$ & $\begin{array}{l}29725.679 \\
(1.363)\end{array}$ & $\begin{array}{l}.637 \\
(0.588)\end{array}$ \\
\hline $\begin{array}{l}\text { R-Square } \\
\text { R Adjusted } \\
\text { F - ratio }\end{array}$ & $\begin{array}{l}0.685 \\
0.618 \\
14.710^{\star \star *}\end{array}$ & $\begin{array}{l}0.655 \\
0.609 \\
11.711^{\star * *}\end{array}$ & $\begin{array}{l}0.616 \\
0.597 \\
12.27^{\star \star *}\end{array}$ & $\begin{array}{l}0.765 \\
0.733 \\
16.144^{\star \star \star}\end{array}$ \\
\hline
\end{tabular}

Field Survey, 2019 Key: * Significance at 10\%, ** Significance at 5\%, ${ }^{\star \star \star}$ Significance at $1 \%{ }^{\star \star \star *}$, $+=$ Lead Equation and the values in bracket are the $t$-value

The coefficient of age was statistically significant at $5 \%$ and negatively related extent of use of improved goat production technologies in the study area. This implies that as the age of farmers' increase, their extent of use of improved goat production technologies decreases. This inverse relationship implies that the age of the farmers' increase, their extent of use of improved goat production technologies in the study area decrease. The result is in agreement with Nwachukwu and Berekwu., (2020) that age of respondents is negatively related to adoption of improved production technology.

The coefficient of education was positively related and statistically significant at $5 \%$ level of probability. The result implied that an increase in the level of education of the 
Creative Commons User License: CC BY-NC-ND

Abstracted by: EBSCOhost, Electronic Journals Service (EJS),

Google Scholar, Journal Seek, Scientific Commons,

Food and Agricultural Organization (FAO), CABI and Scopus
Journal of Agricultural Extension

Vol. 25 (2) April, 2021

ISSN(e): 24086851; ISSN(Print); 1119944X

http://journal.aesonnigeria.org

http://www.ajol.info/index.php/jae

Email: editorinchief@aesonnigeria.org

respondents in the study area will lead to a corresponding increase extent of use of improved goat production technologies in the study area. The result conforms to the researchers a prior expectation that education enhance farmers' awareness, access to market as well as enhances extent of use of improved goat production technologies.

The coefficient of coefficient of house size was positively related and statistically significant at $5 \%$ level of probability. This result of implies that an increase in household size will result to a corresponding increase in the extent of use of improved goat production technologies in the study area. Similarly, Ugboaja and Onu (2019) opined that household size suggests is a determinant of use of improved farming technology.

The coefficient of farming experience was significant at $5 \%$ and positively related to extent of use of improved goat production technologies in the study area. The result implied that a unit increase in the years of farming will lead to an increase in the extent of use of improved goat production technologies in the study area. In agreement with this result, Onu and Maduka (2017) also found that farming experience has shown to enhance the participation increasing agricultural output.

The coefficient of annual farm size was statistically significant at $5 \%$ and positively related to the extent of use of improved goat production technologies in the study area. This result implies that a unit increase in the farmers' farm size will lead to a corresponding increase in the extent of use of improved goat production technologies in the study area.

The coefficient of income was statistically significant at $5 \%$ and it is positively related to extent of use of improved goat production technologies in the study area. This implies that a unit increase in income will lead to an increase in extent of use of improved goat production technologies in the study area. This may be attributed to the fact that an increase in income will enable the farmers to adopt new farming strategies, buy new equipment, ease transportation and improves investment into the enterprise.

The null hypothesis which stated that there is no significant relationship between farmer's socio-economic characteristics and the extent of improved goat production technologies in the study area was therefore rejected at $5 \%$ alpha level and concluded otherwise.

\section{Constraints to Use of Improved Goat Production Technologies}

Table 5 shows distribution of respondents based on the constraints to use of improved goat production technologies. The result revealed that lack of access to credit $(100 \%)$, lack of credibility from source $(100 \%)$, afraid of taking risk $(99.2 \%)$, difficulty in applying technology (93.3\%), farm size is small $(86.7 \%)$, the technologies expensive to adopt $(76.7 \%)$, cultural or religious belief $(75.8 \%)$, lack of vetinary expert $(60.8 \%)$, procedure were difficult to understand $(58.8 \%)$ and lack of technical 
Creative Commons User License: CC BY-NC-ND

Abstracted by: EBSCOhost, Electronic Journals Service (EJS), Google Scholar, Journal Seek, Scientific Commons,

Food and Agricultural Organization (FAO), CABI and Scopus

http://eoi.citefactor.org/10.11226/v25i2
Journal of Agricultural Extension

Vol. 25 (2) April, 2021

ISSN(e): 24086851; ISSN(Print); 1119944X

http://journal.aesonnigeria.org

http://www.ajol.info/index.php/jae

Email: editorinchief@aesonnigeria.org

support $(57.5 \%)$ were the constraints faced by the respondents in their use of improved goat production technologies

Table 5: Constraints to use of improved goat production technologies Constraints to use of improved goat production Percentage technologies

The technologies expensive to adopt

Procedures were difficult to understand

Lack of veterinary experts around you

Technologies were against your cultural or religious beliefs

Lack of access to credit 100.0

Lack of credibility from source

Farm size is small

Difficulty in applying technology

Lack of technical support

57.5

You were afraid of taking risk

99.2

\section{Source: Field Survey, 2019}

Multiple responses recorded ${ }^{*}$

This result implied that goat farmers encountered series of constraints in the use of goat production technologies. The finding is in tandem with Nwachukwu and Berekwu (2020) that goat farmers were constrained by poor veterinary services, inadequate skilled labour, poor housing facilities, poor road network, market problems, high diseases and pest incidence, high cost of drugs and feeds as major constraints faced by the goat farmers in the study area. More so, Krishna, Mahesh, Lal, and Chhetrib., (2019) found that cost technologies and lack of access to farm credit were hindered goat farmers from adopting improved production technologies.

\section{Conclusion and Recommendations}

The respondents, highly utilized the available improved production technologies. Poor financial status, poor educational background, small size of holding, lack of access to credit, lack of technical support, were serious constraint to use of improved goat production technologies. Credit should be made available to farmers by relevant governmental and non- governmental agencies to increase the level of use of available improved technologies. Again agricultural development programmes (ADPs) should provide necessary technical support to the farmers when needed.

\section{References}

Abia State Agricultural Development Programme (2019) Annual report

Bishop S. and Morris C. (2017). Genetics of disease resistance in sheep and goats. Small Ruminant Research., 70 (1), 48-59 
Creative Commons User License: CC BY-NC-ND

Abstracted by: EBSCOhost, Electronic Journals Service (EJS),

Google Scholar, Journal Seek, Scientific Commons,

Food and Agricultural Organization (FAO), CABI and Scopus

http://eoi.citefactor.org/10.11226/v25i2
Journal of Agricultural Extension

Vol. 25 (2) April, 2021

ISSN(e): 24086851; ISSN(Print); 1119944X

http://journal.aesonnigeria.org

http://www.ajol.info/index.php/jae

Email: editorinchief@aesonnigeria.org

Food and Agriculture Organisation (FAO) (2015). FAOSTAT Database. Food and Agricultural Organisation of United Natiions. Accessed May 2016, available at http://faostat.fao.org/site/617/default.aspxAancor..

Karbo, N., Otchere, E.O., Bruce, J., Salia, P. and Honya, G. (2017). Small ruminants ownership pattern, flock structure and aspects of their performance in a sedentary crop-livestock system of the Upper East region of Ghana. Ghanaian Journal of Animal Science, 1 (2-3), 121-128.

Krishna A. P, Mahesh J. O, Lal B. C, Santosh K. W, and Bishnu P. K., (2019) adoption of goat production technology and its impact among rural farmers in Nawalparsi District of Nepal. Journal Agercolere 1(1) Pp1-5

Nwachukwu C.U. and Berekwu N. (2020). Production and management of goat rearing in rural areas of Ezinihitte Mbaise, Imo State, Nigeria. Agro-Science, 19 (3), 25-31.

Onu, S.E. and Maduka, O.A. (2017) Assessment of conservation measures of selected tree crops going into extinction adopted by rural farmers in Ohafia L.G.A of Abia State, Nigeria. International Journal of Agricultural and Earth Science (IJAES). 2(6). Pp 23-31

Peacock, C. (2015). Goats-A pathway out of poverty. Small Ruminant Research, 60(1), 179-186.

Singh., I. G (2017) Effects of protein supplementation of young sheep on resistance development and resilience to parasite nematode. Aust J Exp Agric; 43: 1469-1476.

Susan A.M., David R.S., and Travis R.W (2020) Sustainable sheep and goat production through strategic nutritional management and advanced technologies. Sustainability, Challenges and Innovations. Journal of Bussiness Management and Economics, 3(2), 1-6. Pp231-246

Ugboaja C. I and Onu, S. E (2019) Farmers Utilization of Existing and Emerging Technologies for Cassava Production in Enugu State, Nigeria. Journal of Agricultural Extension Vol. 23 (2) April, 2019.Pp 39-46. 